\title{
Reduced kinetic model for the combustion of n-cetane and heptamethylnonane based on a primary reference fuel reduced kinetic model
}

\section{$\operatorname{AUTHOR}(\mathrm{S})$ :}

Kawanabe, Hiroshi; Ishiyama, Takuji

\section{CITATION:}

Kawanabe, Hiroshi ...[et al]. Reduced kinetic model for the combustion of $n$-cetane and heptamethylnonane based on a primary reference fuel reduced kinetic model. International Journal of Engine Research 2021, 22(7): 2203-2212

ISSUE DATE:

2021-07-01

URL:

http://hdl.handle.net/2433/264615

\section{RIGHT:}

This is the accepted manuscript of the foll lowing article: 'International Journal of Engine Research' Volume: 22 issue: 7, page(s): 2203-2212. Copyright ( I IMechE 2021. DOl: 10.1177/1468087420931969;; This is not the published version. Please cite only the published version.この論文は出版社版でありません。引用の際には出版社版をご確認ご利用くた さい。 


\title{
Reduced Kinetic Model for the Combustion of n-Cetane and Heptamethylnonane based on a Primary Reference Fuel Reduced Kinetic Model
}

\author{
Hiroshi Kawanabe and Takuji Ishiyama \\ Graduate School of Energy Science, Kyoto University \\ Yoshida Honmachi, Sakyo-ku, Kyoto, 606-8501 Japan
}

Key words: Reduced kinetic model, Diesel-PRF, Ignition delay time, Diesel spray combustion

\begin{abstract}
A reduced kinetic model for the combustion of n-heptane, i-octane, n-cetane and heptamethylnonane was developed based on a prior model designed for use with a primary reference fuel consisting of n-heptane and i-octane. The present model, which can be easily employed in conjunction with a conventional computational fluid dynamics (CFD) code, contains 59 chemical species and 96 reactions. Predicted ignition delay times under high pressure and temperature conditions were generated using this new kinetic model and compared with those obtained from full kinetic models. The results indicate that the general trends exhibited by the ignition delay times as temperature and pressure are varied are accurately predicted with this reduced model. The present model was also combined with a commercial CFD code and used to simulate the ignition of a diesel spray at high pressure and temperature. Finally, the effects of the cetane number of the fuel on the ignition process were investigated.
\end{abstract}

\section{INTRODUCTION}


Premixed charge compression ignition (PCCI)-based combustion, which includes PCCI, partial PCCI and modulated kinetics combustion, is characterized by reduced heterogeneity in the fuel-air mixture and a low flame temperature[1]. This process has been intensively investigated in a view point of its potential to drastically reduce the nitrogen oxides and particulate matter emissions from diesel engines. Recently, this combustion technique is widely used because it is effective at controlling emissions under low engine loads at which catalytic converters are not fully activated, due to the low exhaust gas temperature.

PCCI based combustion is suitable for low-load operation. For all-load operations, including higher load ranges, conventional diesel combustion with exhaust catalysts should be used; therefore, engine specifications should be also suitable for diesel operation. For this reason, very high EGR ratio (50 per cent) and slightly reduced compression ratios are now considered to be effective for proper combustion phasing with moderate advance of injection timing for the PCCI mode. In PCCI combustion, fuel-air mixing occurs simultaneously with the progression of the chemical reactions. In the long ignition delay cases, the fuel-air mixture becomes more homogeneous, therefore, various combustion characteristics, including the ignition delay and combustion duration, are greatly affected by the chemical reaction rate. The available range of engine output is restricted, because lean mixtures lead to misfires while rich mixtures tend to produce knocking-like combustion. In addition, it is difficult to adjust the ignition timing to achieve high thermal efficiency. The appropriate exhaust gas recirculation rate, effective compression ratio and injection conditions must therefore be selected to suppress misfires and knocking, and to optimize the ignition timing [2]. The development of a general strategy for selecting these combustion control parameters requires a basic understanding of the effects of mixing and chemical processes on ignition and combustion. However, basic knowledge in these areas is still limited, due to the 
complexity of the phenomena associated with the mixing and chemical processes and the associated interactions.

Computational fluid dynamics (CFD) is a powerful tool for the detailed investigation of combustion processes, and so has been widely used. Kong et al. employed CFD in conjunction with a diesel combustion model to assess PCCI combustion and demonstrated that the calculation results agreed with experimental data [3, 4]. A large eddy simulation was used by Saijo et al. to describe the non-homogeneity of fuel-air mixtures [5]. The authors have also investigated the auto-ignition of non-homogeneous mixtures by applying a novel combustion model that examines the effects of the turbulent mixing rate on ignition during both diesel and PCCI combustion $[6,7]$. In many such calculations, n-heptane is used as a model fuel because the resulting oxidation process can be described by reduced kinetic models or by simplified small models, such as the Shell model [8], Schreiber's model [9] or a global reduced model[10]. Various n-heptane reduced kinetic models have been proposed by Patel et al. [11] (consisting of 29 chemical species and 52 reactions), Peters et al. [12] (26 chemical species and 30 reactions) and Maroteaux et al. [13] (25 chemical species and 26 reactions). Employing a mixture of n-heptane and i-octane as the primary reference fuel (PRF), Tanaka et al. developed a reaction model consisting of 32 species and 55 reactions [14], while Tsurushima proposed a model comprising 33 species and 38 reactions [15]. Moreover, our own group developed a PRF model [7] based on 42 species and 69 reactions that was combined with CFD to simulate the ignition process of a diesel spray. Despite the intensive development of PRF reaction models, few models applicable to CFD have been provided for use with higher molecular weight hydrocarbons, which are the primary constituents of the fuels actually used in diesel engines. Poon et al. has developed a reduced reaction model of mixed fuel of n-hexadecane, heptamethylnonane, and cyclohexane, which consists with 89 chemical species and 319 
reactions[16]. Also, a skeletal mechanism of multicomponent blend as a diesel fuel surrogate was developed. This model consists of n-dodecane and m-xylene skeletal kinetics which has 163 species and 887 reactions[17]. These reaction models reproduce the ignition process of a real diesel fuel, however, still are large kinetics sets for applying to CFD calculation. In order to investigate ignition and combustion processes by CFD using physical and chemical characteristics close to those of real fuels, it is necessary to develop a compact reaction model with an acceptable level of accuracy for larger hydrocarbons.

In the present study, a reduced kinetic model for a PRF consisting of n-cetane and heptamethylnonane (HMN) was developed. The present model, which can readily be applied to a conventional CFD code, is relatively simple and is constructed from 59 chemical species and 96 reactions. Ignition delay times were initially calculated for a homogeneous fuel-air mixture under pressurized high temperature conditions using this model and the results were compared with those obtained from full kinetic models. This new model was also employed in conjunction with a commercial CFD code to simulate the ignition of a diesel spray at high pressure and temperature. The effects of the cetane number $(C N)$ of the fuel on the ignition process were also assessed.

\section{MODEL DESCRIPTION}

A reduced kinetic reaction of n-cetane and HMN was developed via an empirical method based on a n-heptane and i-octane (PRF) model of 42 chemical species and 69 reactions [7]. The reaction set for the PRF reduced kinetic model consisted of three parts: decomposition and partial oxidation reactions from n-heptane to $\mathrm{C} 3$ hydrocarbons, decomposition and partial oxidation reactions from i-octane to $\mathrm{C} 3$ hydrocarbons, and oxidation reactions of $\mathrm{C} 3$ hydrocarbons. A similar 
set of reactions was employed to produce a reduced kinetic reaction model for the n-cetane and HMN fuel.

In the PRF reduced kinetic model, the decomposition and partial oxidation reactions of the fuel (represented by RH) are as follows [7].

$$
\begin{array}{ll}
\mathrm{RH}+\mathrm{OH} & \rightarrow \mathrm{R}+\mathrm{H}_{2} \mathrm{O} \\
\mathrm{R}+\mathrm{O}_{2} & \rightarrow \mathrm{RO}_{2} \\
\mathrm{RO}_{2} & \rightarrow \mathrm{QOOH} \\
\mathrm{QOOH}+\mathrm{O}_{2} & \rightarrow \mathrm{O}_{2} \mathrm{QOOH} \\
\mathrm{O}_{2} \mathrm{QOOH} & \rightarrow \text { Ket }+\mathrm{OH} \\
\mathrm{Ket} & \rightarrow \text { Fragments }+\mathrm{OH}
\end{array}
$$

Here, "Ket" represents a keto-hydroperoxide and "Fragments" represents smaller hydrocarbons (those having a carbon number less than 3). As the first step in the development of a reduced model, a reaction set like reactions (1) through (6) was employed for the combustion of n-cetane and HMN. It was assumed that the fuel molecules were decomposed into smaller hydrocarbons via only one mechanism, based on low temperature oxidation. Here, based on the calculation result of ignition processes for $n$-heptane and n-cetane mixture, using full kinetics chemistry model under the same condition, temporal changes of temperature are similar for these two fuels. However, this reduced model could not predict the auto-ignition delay time for n-cetane mixture, even upon adjusting the frequency factor for each reaction. The temperature increase resulting from low temperature oxidation predicted by the reduced kinetic model was less than that obtained from the full kinetic model, and so the ignition delay time calculated by the reduced kinetic model was much longer. 
Reactions (1) through (6) indicate that two $\mathrm{OH}$ are derived from each fuel molecule, and the fuel mole fraction in the n-cetane mixture is only half that in an n-heptane mixture at the same equivalence ratio, such that the heat release from low temperature oxidation is underestimated.

This difference between n-heptane and n-cetane cases indicates that the "Fragments" in reaction (6) in the n-cetane mechanism may include not only $\mathrm{C} 3$ smaller hydrocarbons but also relatively large hydrocarbons. These larger hydrocarbons would be further oxidized by a reaction path similar to reactions (1) through (6), leading to increased generation of $\mathrm{OH}$. The results of calculation taking into account the detailed combustion chemistry of n-cetane[18] show that $\mathrm{OH}$ would be produced not only by reactions (5) and (6) but also by the reactions listed below. Thus, reactions (7) through (11) should be included in the reduced model because the $\mathrm{OH}$ generation rate via reactions (7) through (11) is not negligible.

$$
\begin{aligned}
& \mathrm{C}_{16} \mathrm{H}_{34} \quad \rightarrow \mathrm{C}_{10} \mathrm{H}_{21}+\text { Fragments } \\
& \mathrm{C}_{10} \mathrm{H}_{21}+\mathrm{O}_{2} \rightarrow \mathrm{C}_{10} \mathrm{H}_{21} \mathrm{O}_{2} \\
& \mathrm{C}_{10} \mathrm{H}_{21} \mathrm{O}_{2} \rightarrow \mathrm{C}_{10} \mathrm{H}_{20} \mathrm{OOH} \\
& \mathrm{C}_{10} \mathrm{H}_{20} \mathrm{OOH} \rightarrow \text { Cycloether }+\mathrm{OH} \\
& \mathrm{C}_{10} \mathrm{H}_{20} \mathrm{OOH} \rightarrow \text { Fragments }+\mathrm{OH}
\end{aligned}
$$

In the present model, instead of employing this reaction path via (7) to (11), an alternative method was used to reduce the computational load. In this method, reactions (1) through (6) of n-heptane were employed in place of reactions (8) through (11), as this generated similar results. In addition, two reactions were added after reaction (6) (n-cetane reactions (8) and (9) in Table 1). In this modified method, a portion of the "Fragments" generate $\mathrm{C}_{7} \mathrm{H}_{14}$ via reactions (1) through (6), 
while the remaining products are hydrocarbons with three or less carbons that subsequently undergo oxidation. Table 1 summarizes the reaction systems in the present model, in which the fuels n-cetane, HMN, n-heptane and i-octane are transformed to $\mathrm{C} 3$ paraffins. The final reaction sets for the four fuels were established by including C3 oxidation reactions extracted from Patel's model [11]. The low temperature part of the reaction system is described in Table 1, which includes 59 species and 96 reactions and can be used with CFD calculations. Table 1 also provides the preexponential factor for each reaction. These factors were selected such that the calculated delay times associated with the low temperature heat release and hot flame ignition of homogeneous fuel-air mixtures agreed with those calculated employing full kinetic reaction model.

\section{HOMOGENEOUS MIXTURE IGNITION PROCESS}

Using the newly developed model, the ignition processes in a homogeneous fuel-air mixture at high temperatures and pressures similar to those encountered in an actual engine were calculated for the four fuels and compared with the results obtained using the full kinetic reaction model. Figure 1 plots the ignition delay time against the initial temperature, $T_{i}$, at constant pressures of $p_{\mathrm{i}}=$ 2 or $4 \mathrm{MPa}$. In this figure, the thick and thin lines represent the results of the present model and those of the full kinetic reaction model, respectively. In the present study, each full kinetic reaction model was generated using the Knowledge-basing Utilities for Complex Reaction System (KUCRS) software developed by Miyoshi $[18,19]$ and the thermodynamic data were obtained using the THERM software written by Ritter and Bozzeli [21]. Arrhenius plots of the ignition delays are shown for n-heptane, i-octane, n-cetane and HMN under high pressure conditions of $p_{\mathrm{i}}=2$ and 4 $\mathrm{MPa}$. These data were acquired at equivalence ratios from 0.5 to 3.0. The ignition delay results obtained from the present model are evidently in good agreement with those from the full kinetic 
model. In addition, the negative temperature coefficient (NTC) phenomenon is well reproduced by the new model between $T_{i}=800$ and $1000 \mathrm{~K}$ for the n-heptane. However, the present model slightly underestimates the ignition delay times around $T_{i}=1100 \mathrm{~K}$ for $p_{\mathrm{i}}=2$ and $4 \mathrm{MPa}$, such that the ignition delays for n-cetane are slightly less than those predicted by the full kinetics model.

The effects of the equivalence ratio on the ignition delay when using the present model were subsequently examined, using the new model to predict the diesel spray combustion process. The ignition delays calculated using this model were compared with those from the full kinetics model at various equivalence ratios and temperatures. In these trials, a relatively low temperature fuel was injected into a high-temperature gas, whereupon the fuel evaporated and mixed adiabatically with the ambient gas, meaning that the temperatures of rich and lean mixtures were relatively low and high, respectively, while the combustion reactions proceeded simultaneously with the mixing process. Figure 2 shows the relationship between the equivalence ratio, $\phi$, and the temperature of the mixture. The fuel temperature, $T_{\text {fuel }}$, was fixed at $350 \mathrm{~K}$ and the ambient air temperature, $T_{\text {amb }}$, was varied from 700 to $1100 \mathrm{~K}$ based on the latent heat of vaporization of $\mathrm{n}$-heptane. The adiabatic mixing temperatures applied for each fuel were almost equal. Using these relationships between $\phi$ and $T_{\mathrm{i}}$, the ignition delay, $\tau$, was calculated for each of the four fuels, with the results presented in Figure 3. From these data, it is evident that $\tau$ has a minimum at a specific value of $\phi$ for each fuel and each $T_{\text {amb. }}$ As well, the $\phi$ value associated with the minimum $\tau$ becomes larger with increasing $T_{\mathrm{amb}}$, with the exceptions of $T_{\mathrm{amb}}=1100 \mathrm{~K}$ for i-octane and HMN. $\phi$ giving minimum $\tau$ for $T_{\mathrm{amb}}=$ 1100K of i-octane and HMN fuels becomes leaner. For each set of conditions, the results obtained from the present model agree with those generated by the full kinetic reaction model.

\section{DIESEL SPRAY IGNITION PROCESS}


The present kinetic model was used together with a commercial CFD code (AVL FIRE Ver. 2010). Calculations predicting the ignition and combustion processes in a diesel spray were conducted, based on a constant volume vessel under high pressure and temperature conditions. The results of these calculations were compared with experimental data. Figure 4 shows the constant-volume vessel used in the experimental work (left) and the grid system used for calculations, consisting of 120,960 cells (right). In this experiment, ignition and combustion processes of a diesel spray, which is formed by injecting the n-cetane/HMN fuel into high-pressure and high-temperature gas in a constant-volume vessel, were investigated. For calculating the diesel spray, wave break-up model [20] proposed by Liu et al. was employed and the empirical constants $B_{0}$ and $B_{1}$ in the wave model were determined from the experimental trials to be 0.61 and 10 , respectively. The spray half cone angle was assumed to be $4^{\circ}$ and the injection pressure, $p_{j}$, and duration, $t_{j}$, were set to $120 \mathrm{MPa}$ and $2.0 \mathrm{~ms}$, respectively. The nozzle had a single hole with a diameter, $d_{0}$, of $0.18 \mathrm{~mm}$ and the mass of injected fuel, $m_{f T}$, was $19.64 \mathrm{mg}$. In these calculations, the initial pressure and temperature distribution at the start of the injection were based on the experimental procedure. Calculations were performed to assess the heat release from the spray combustion under pressurized, high temperature conditions in a constant volume combustion vessel, using an ultra-lean mixture combustion. During the cooling process following combustion (assisting by the stirrer shown in Figure 4), the injection started at a set pressure, $p_{\mathrm{i}}$ (which was measured), and a temperature, $T_{\mathrm{i}}$, which was calculated from the mass of the mixture and the pressure. During these trials, the temperature increased in the center of the vessel and decreased near the walls during the cooling process. Therefore, the temperature profile employed for the calculations at the start of injection was obtained by modeling this cooling process. Figure 5 presents the temperature distribution and the cross-sectional profile along the line $\mathrm{A}-\mathrm{A}^{\prime}$ at the start of the injection for $p_{\mathrm{i}}=$ 
$4 \mathrm{MPa}$ and $T_{\mathrm{i}}=900 \mathrm{~K}$. Here, fluid motion induced by the stirrer is observed and this velocity field is approximately the same as the experiment condition. The maximum temperature in the center region eventually becomes more than $100 \mathrm{~K}$ higher than $T_{\mathrm{i}}$.

The macroscopic characteristics of the spray development were examined by comparing the predicted spray tip penetration, $x_{\mathrm{tip}}$, and liquid-phase penetration, $x_{\mathrm{drp}}$, with those measured experimentally using the shadowgraph method. The associated data are provided in Figure 6 for $p_{\mathrm{i}}=$ 2 and $4 \mathrm{MPa}$. Here, the calculated $x_{\text {tip }}$ and $x_{\text {drp }}$ values represent the furthest positions of the fuel-air mixture and the fuel droplets, respectively, and the symbols and lines indicate experiment data and calculation results, respectively.

The ignition and combustion processes of the diesel spray were calculated for a binary n-cetane/HMN fuel and the effects of the $C N$ of the fuel on ignition were investigated. Figure 7 shows the temporal variations of the pressure change, $p-p_{\mathrm{i}}$, and the pressure gradient, $d p / d t$, for $C N$ $=40$ and 90 at both $p_{\mathrm{i}}=2 \mathrm{MPa}, T_{\mathrm{i}}=900 \mathrm{~K}$ and $p_{\mathrm{i}}=4 \mathrm{MPa}, T_{\mathrm{i}}=900 \mathrm{~K}$, and also compares the calculation results (red lines) with experimental data (black lines). The $d p / d t$ values in these plots reflect the heat release rates. From these data, it is evident that the calculation results accurately reproduce the experimental values with regard to the ignition delay trends and variations in the heat release rates. However, the $p-p_{\mathrm{i}}$ values toward the end of combustion are overestimated in the calculation results. This result may possibly be due to a lack of accuracy in estimating the heat loss. Subsequently, the spray development and flame expansion were examined, and Figure 8 shows the experimental (based on shadowgraph images) and calculated temporal changes at a constant temperature of $T=2000 \mathrm{~K}$, with $p_{\mathrm{i}}=4 \mathrm{MPa}$ and $T_{\mathrm{i}}=900 \mathrm{~K}$. The $C N$ values applied during the calculations and experimental work were 40 and 45, respectively. Under these conditions, the $\tau$ value was approximately $1 \mathrm{~ms}$ and ignition occurred near the tip of the spray. The spray 
subsequently impinged on the chamber wall and the high temperature region spread along the wall. The calculated temporal changes in the high temperature region are seen to be in good agreement with the visual images.

Finally, the effect of the $C N$ on the ignition delay time of the diesel spray was investigated based on the CFD calculations. Figure 9 plots $\tau$ as a function of the n-cetane mass fraction in the n-cetane/HMN fuel, and also shows the $C N$ value of the fuel. In these trials, $p_{i}$ was 4 or $2 \mathrm{MPa}$ and $T_{\mathrm{i}}$ was $900 \mathrm{~K}$. The ignition delay time is seen to have increased with decreases in $C N$ at each initial pressure, in quantitative agreement with the experimental results. In the case of $p_{i}=$ 4MPa, $\tau$ increases gradually as the $C N$ is reduced, going from $0.5 \mathrm{~ms}$ at $C N=90$ to $1.5 \mathrm{~ms}$ at $C N=$ 20. However, at $p_{\mathrm{i}}=2 \mathrm{MPa}, \tau$ increases drastically with decreasing $C N$, especially at $C N$ values below 40. For both conditions, the calculation results show the same trends as the experimental data.

\section{CONCLUSIONS}

A reduced kinetic model was developed for the combustion of n-heptane, i-octane, n-cetane and HMN, based on a prior model using n-heptane and i-octane as the PRF. The present model consists of 59 chemical species and 96 reactions and is readily applied in conjunction with a conventional CFD code. Ignition delay times were determined for a homogeneous fuel-air mixture under high pressure and temperature conditions via the present model and the results were compared with those produced from full kinetic model. Furthermore, the new model was combined with a commercial CFD code and applied to simulations of the ignition of a diesel spray under high pressure and temperature conditions. The effect of the $C N$ of the fuel on the ignition process was also examined. The following conclusions are derived from the results. 
1. The ignition delays produced by the present model were in good agreement with those obtained from the full kinetic model. In particular, the appearance of a negative temperature coefficient between an initial temperature of 800 and $1000 \mathrm{~K}$ was successfully predicted for $\mathrm{n}$-heptane. However, the present model slightly underestimated the ignition delay time around $1100 \mathrm{~K}$ at pressures of 2 and $4 \mathrm{MPa}$.

2. The effects of the equivalence ratio were assessed using the new model in the case of adiabatic low temperature mixing of the fuel and high temperature air. The ignition delay was found to have a minimum value at a specific equivalence ratio for all fuels at ambient temperature. In addition, the equivalence ratio giving the minimum ignition delay became larger with increasing gas temperature. For all conditions, the results obtained from the present model agreed with those generated by the full kinetic reaction model.

3. An ignition delay of approximately $1 \mathrm{~ms}$ was determined for a $C N$ of 40 , with ignition at the tip of the spray. As a result, the spray impinged on the combustion chamber wall and the high temperature region spread along the wall. The predicted temporal changes in the high temperature region matched the experimental images.

4. The ignition delay time became longer upon decreasing the $C N$ of the fuel for each initial pressure condition, and this tendency agreed quantitatively with the experimental results. In the case of an initial pressure of $4 \mathrm{MPa}$, the ignition delay time increased slowly, from $0.5 \mathrm{~ms}$ at $C N$ $=90$ to $1.5 \mathrm{~ms}$ at $C N=20$, while at $2 \mathrm{MPa}$ the ignition delay rapidly increased with decreasing $C N$, especially for $C N<40$.

\section{REFERENCES}

1. N. Shimazaki, T Tsurushima and T. Nishimura, "Dual-Mode Combustion Concept with 
Premixed Diesel combustion by Direct Injection near Top Dead Center", SAE Paper, 2003-01-0742.

2. N. Horibe, K. Takahashi, S. S. Kee, T. Ishiyama, M. Shioji, “The Effects of Injection Conditions and Combustion Chamber Geometry on Performance and Emissions of DI-PCCI Operation in a Diesel Engine", Trans. J. Fuels Lub., 116 (4), (2008), pp. 387-395.

3. S. -C Kong, R. D. Reitz, "Modeling HCCI Engine Combustion Using Detailed Chemical Kinetics with Combustion of Turbulent Mixing Effects”, ASME Paper 2000-ICE-306, (2000).

4. S. -C Kong, C. D. Marriott, R. D. Reitz and M. Christensen, "Modeling and Experiments of HCCI Engine Combustion Using Detailed Chemical Kinetics with Multidimensional CFD”, SAE Paper 2001-01-1026, (2001).

5. K. Saijyo, T. Kojima and K. Nishiwaki, "A Numerical Analysis of the Effect of Mixture Heterogeneity on Combustion in a Premixed Charge Compression Ignition Engine", Proc. of COMODIA (2004), B2-3.

6. H. Kawanabe, R. Yamamoto and T. Ishiyama, "Diesel Combustion Model with Auto-ignition Process of Non-homogeneous Mixture”, SAE Paper No. 2009-01-1897 (2009).

7. H. Kawanabe, H. Kojima and T. Ishiyama, "Modeling of the Auto-ignition Process of a Non-homogeneous Mixture in a Diesel Spray for CFD”, SAE Paper, No. 2010-01-0357 (2010).

8. M. P. Halstead, L. J. Kirsch and C. P. Quinn, "The autoignition of hydrocarbon fuels at high temperatures and pressures - Fitting of a mathematical model" Combustion and Flame 30 (1977), pp. 45-60.

9. M. Schreiber, A. S. Sakak, and A. Lingens, "A Reduced Thermokinetic Model for the Autoignition of Fuels with Variable Octane Ratings", Proceedings of 25th international Symposium on Combustion, 1994, pp. 933-940. 
10. S. Gowdagiri, and M. A. Oehlschlaeger, "Global Reduced Model for Conventional and Alternative Jet and Diesel Fuel Autoignition”, Energy and Fuels, 28 (2014), pp. 2795-2801.

11. A. Patel, S.-C. Kong and R. D. Reitz, "Development and Validation of a Reduced Reaction Mechanism for HCCI Engine Simulations”, SAE Paper, 2004-01-0558 (2004).

12. N. Peters, G. Paczko, R. Seiser, K. Seshadri, “Temperature cross-over and nonthermal runaway at two-stage ignition of n-heptane", Combustion and Flame, 128 (2002) pp. 38-59.

13. F. Maroteaux, L. Noel, "Numerical investigations on methods to control the rate of heat release of $\mathrm{HCCl}$ combustion using reduced mechanism of n-heptane with a multidimensional CFD code”, Combust Theory Model (2007) 11:501-25.

14. S. Tanaka, F. Ayala and J. C. Keck, "A reduced chemical kinetic model for HCCI combustion of primary reference fuels in a rapid compression machine", Combustion and Flame 133 (2003) pp. 467-481.

15. T. Tsurushima, "A new skeletal PRF kinetic model for HCCI combustion", Proc. of the Combustion Institute, Vol.32, PartII (2009), pp. 2835-2841.

16. H. M. Poon, K. M. Pang, H. K. Ng, S. Gan, and J. Schramm, "Development of multi-component diesel surrogate fuel models -Part I: Validation of reduced mechanisms of diesel fuel constituents in 0-D kinetic simulations", Fuel, 180 (2018), pp. 433-441.

17. Y. Pei, M. Mehl, W. Liu, T. Lu, W. J. Pitz, and S Som, “A Multicomponent Blend as a Diesel Fuel Surrogate for Compression Ignition Engine Applications”, Journal of Engineering for Gas Turbines and Power, 137-111, Paper No: GTP15-1057 (2015).

18. A. Miyoshi, KUCRS software library, revision $2011.01 .07 \mathrm{m6}$, available from the author. See the web: http://akrmys.com/KUCRS/ for update information. 
19. A. Miyoshi, "Systematic Computational Study on the Unimolecular Reactionsof Alkylperoxy (RO2), Hydroperoxyalkyl (QOOH), andHydroperoxyalkylperoxy (O2QOOH) Radicals”, $J$. Phys. Chem. A., 115 (2011), pp. 3301-3325.

20. E. R. Ritter and J. W. Bozzelli, “THERM: Thermodynamic Property Estimation for Gas Phase Radicals and Molecules”, Int. J. Chem. Kinet., 23, (1991), pp. 767-778.

21. A. B. Liu, D. Mather and R. D. Reitz, "Modeling the Effects of Drop Drag and Breakup on Fuel Sprays", SAE Paper 930072, (1993). 


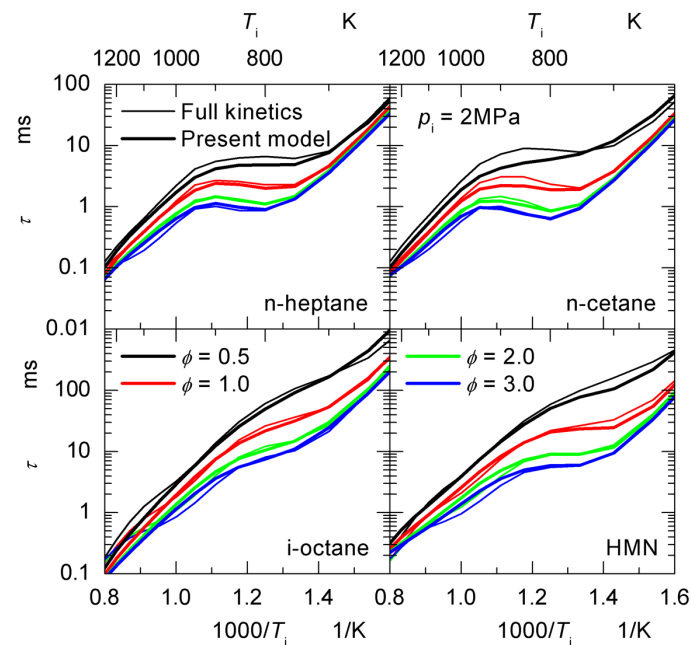

(a) $p_{\mathrm{i}}=2 \mathrm{MPa}$

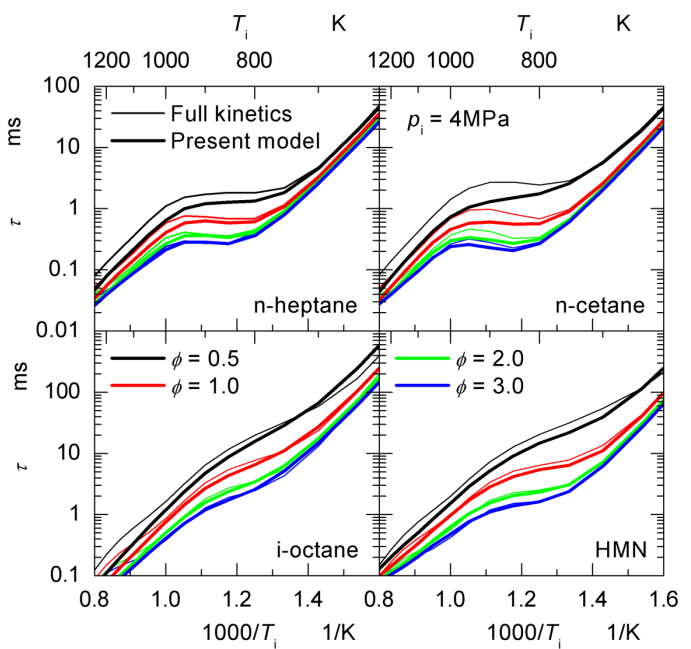

(b) $p_{\mathrm{i}}=4 \mathrm{MPa}$

Figure 1 Change of ignition delay time $\tau$ against initial temperature for various fuels 


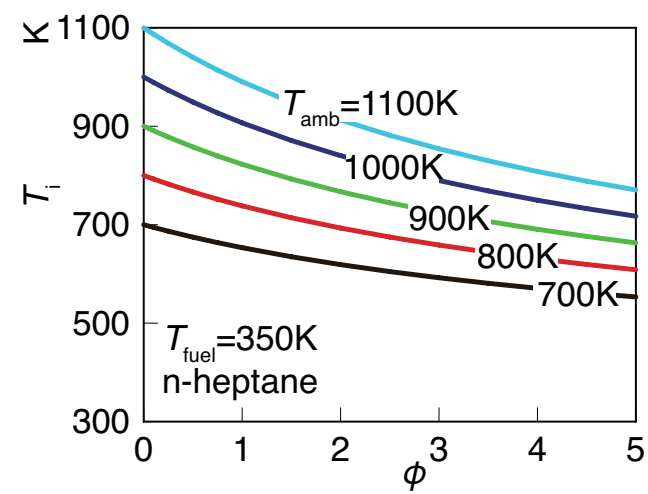

Figure 2 Adiabatic mixing temperature 


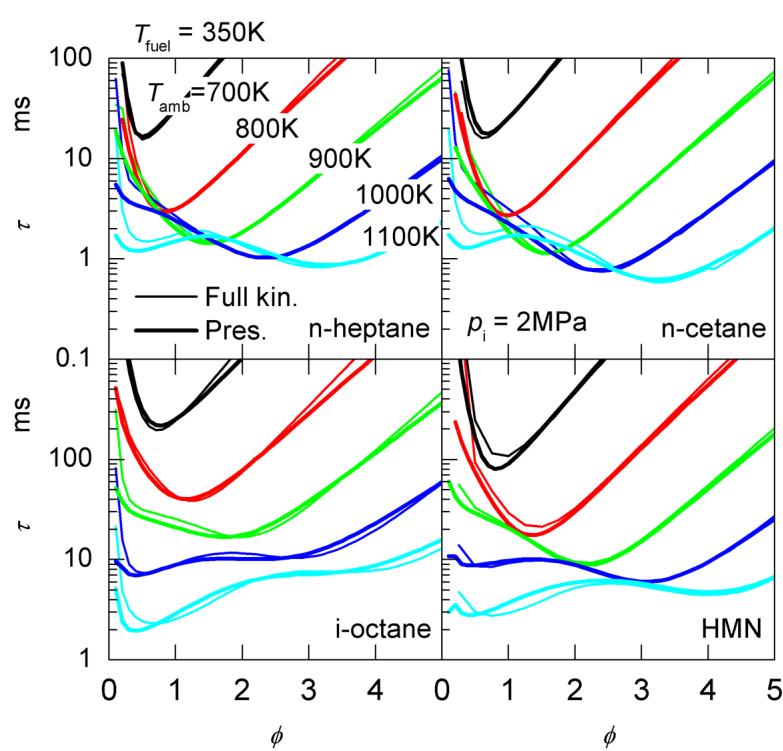

(a) $p_{\mathrm{i}}=2 \mathrm{MPa}$

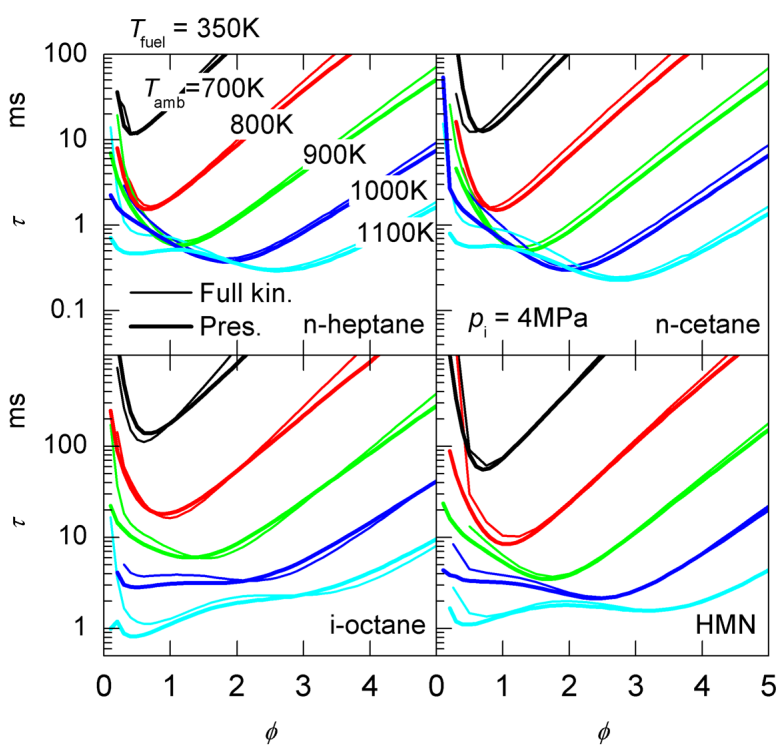

(b) $p_{\mathrm{i}}=4 \mathrm{MPa}$

Figure 3 Change of ignition delay time $\tau$ for adiabatic mixed mixture 


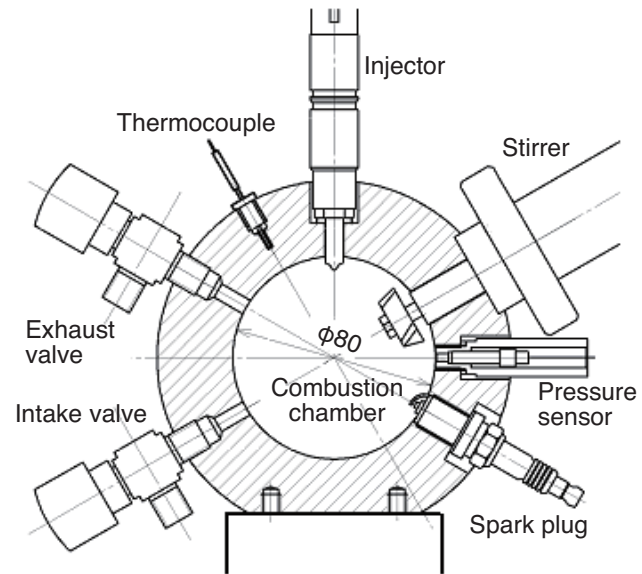

(a) Vessel configuration

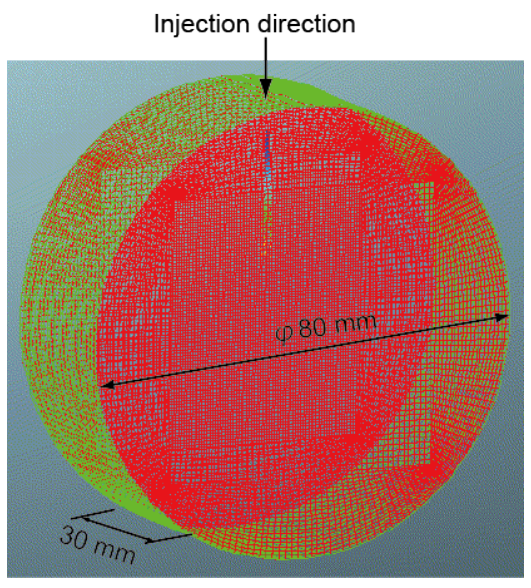

(b) Calculation grid system

Figure 4 Constant volume vessel and grid system for calculation 


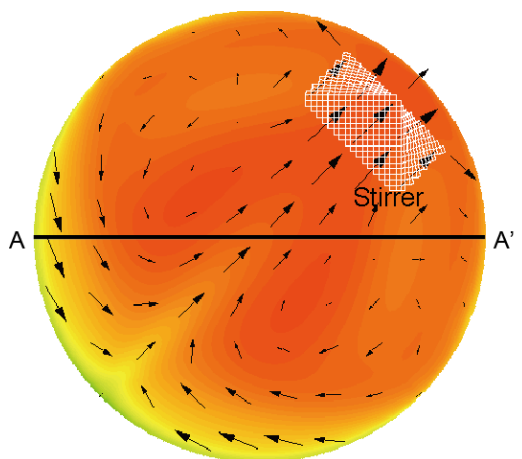

(a) Temperature distribution
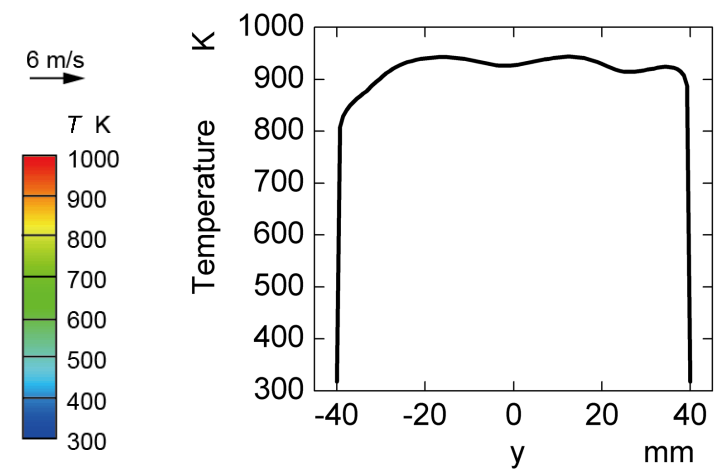
Figure 5 Example of temperature distribution at injection timing

(b) Temperature profile at A-A' cross cut 

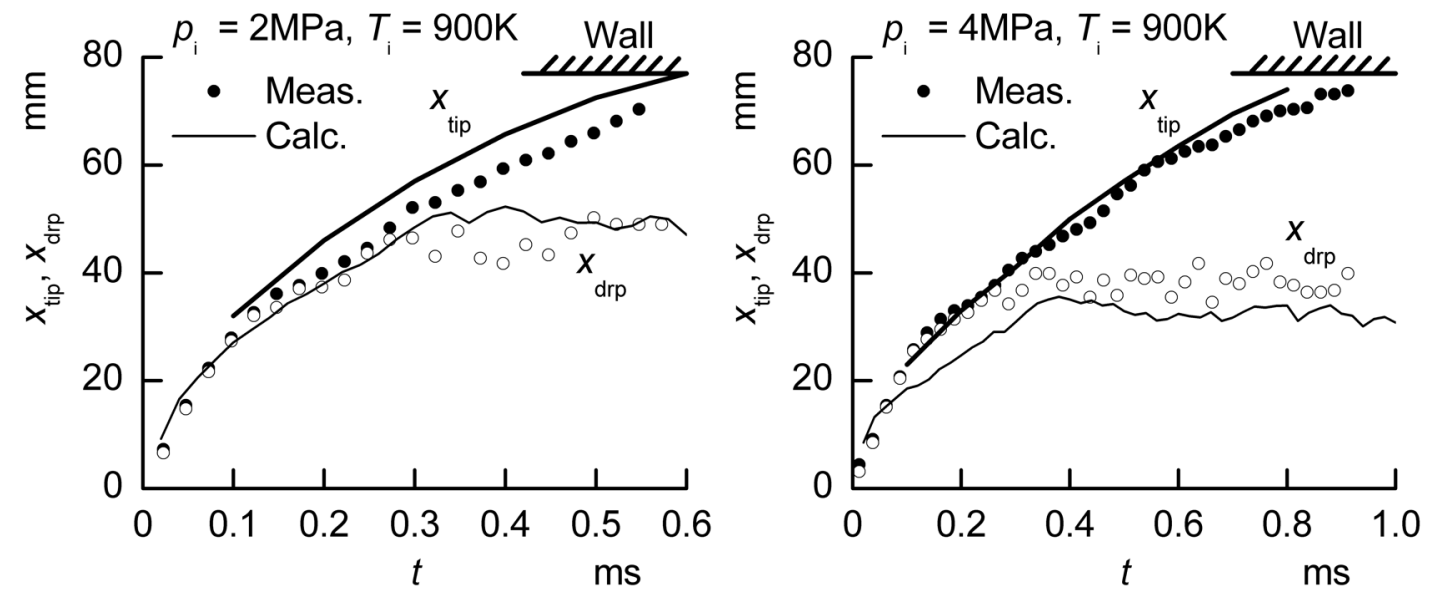

(a) $p_{\mathrm{i}}=2 \mathrm{MPa}$

(b) $p_{\mathrm{i}}=4 \mathrm{MPa}$

Figure 6 Change of spray tip penetration $x_{\text {tip }}$ and droplet penetration $x_{\text {drp }}$ 


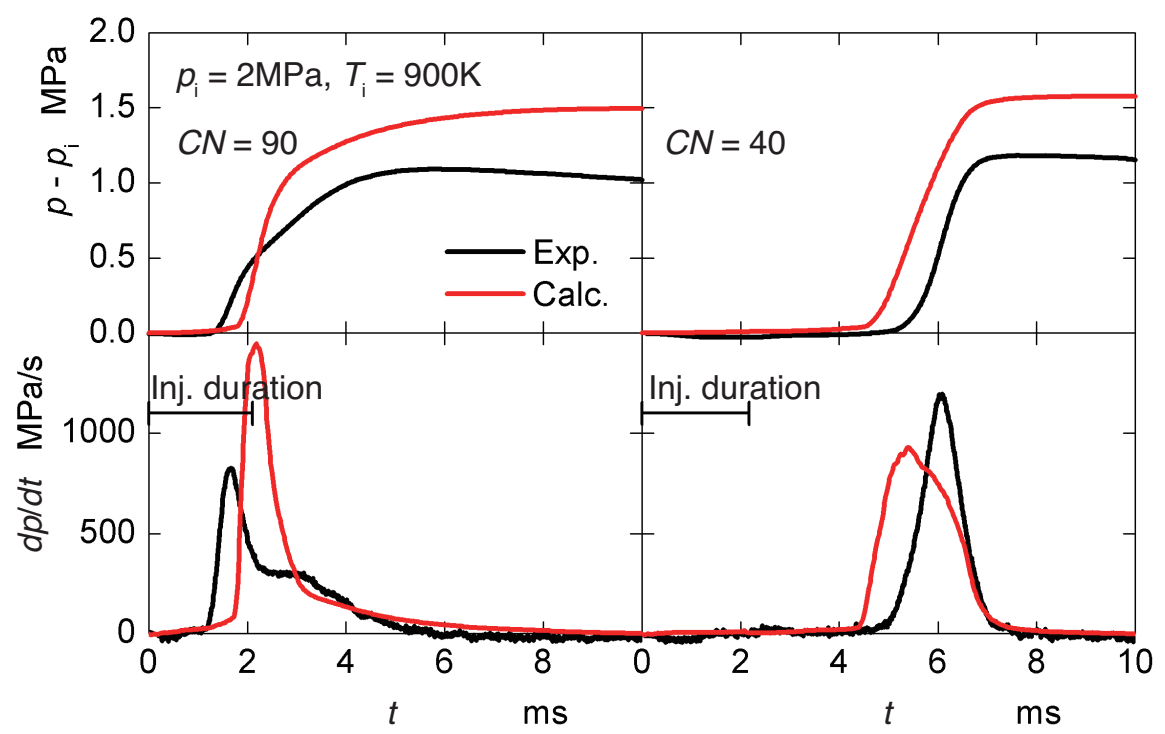

(a) $p_{\mathrm{i}}=2 \mathrm{MPa}, T_{\mathrm{i}}=900 \mathrm{~K}$

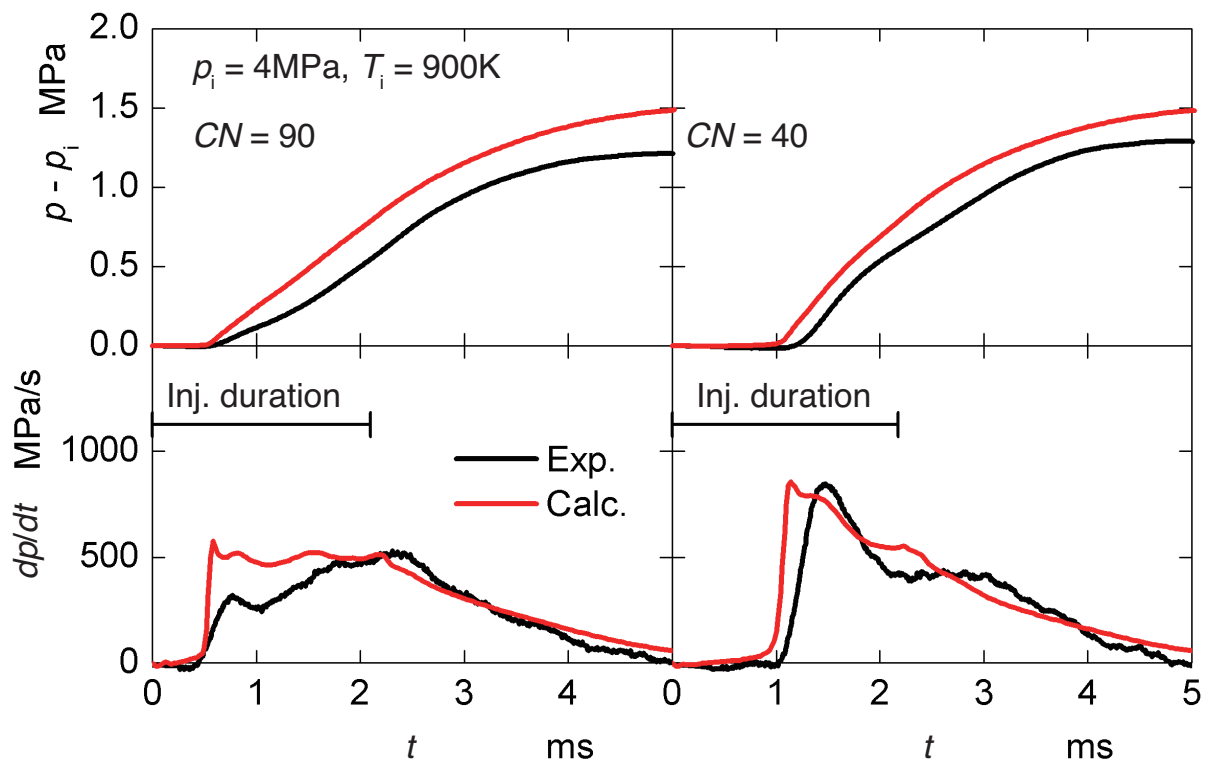

(b) $p_{\mathrm{i}}=4 \mathrm{MPa}, T_{\mathrm{i}}=900 \mathrm{~K}$

Figure 7 Change of pressure $p-p_{\mathrm{i}}$ and pressure rise rate $d p / d t$ 


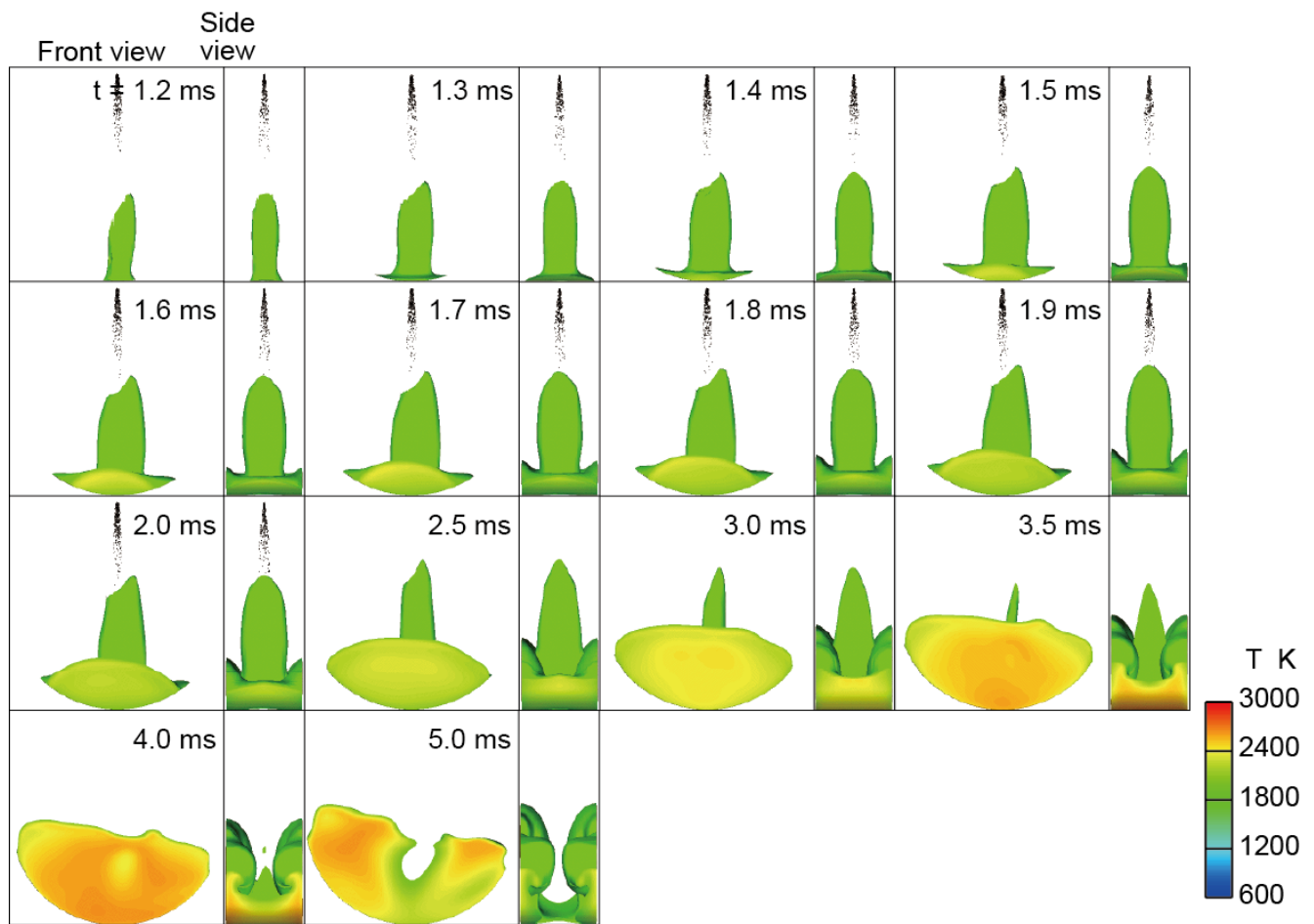

(a) Constant temperature surface $(T=2000 \mathrm{~K})$ for $C N=40$

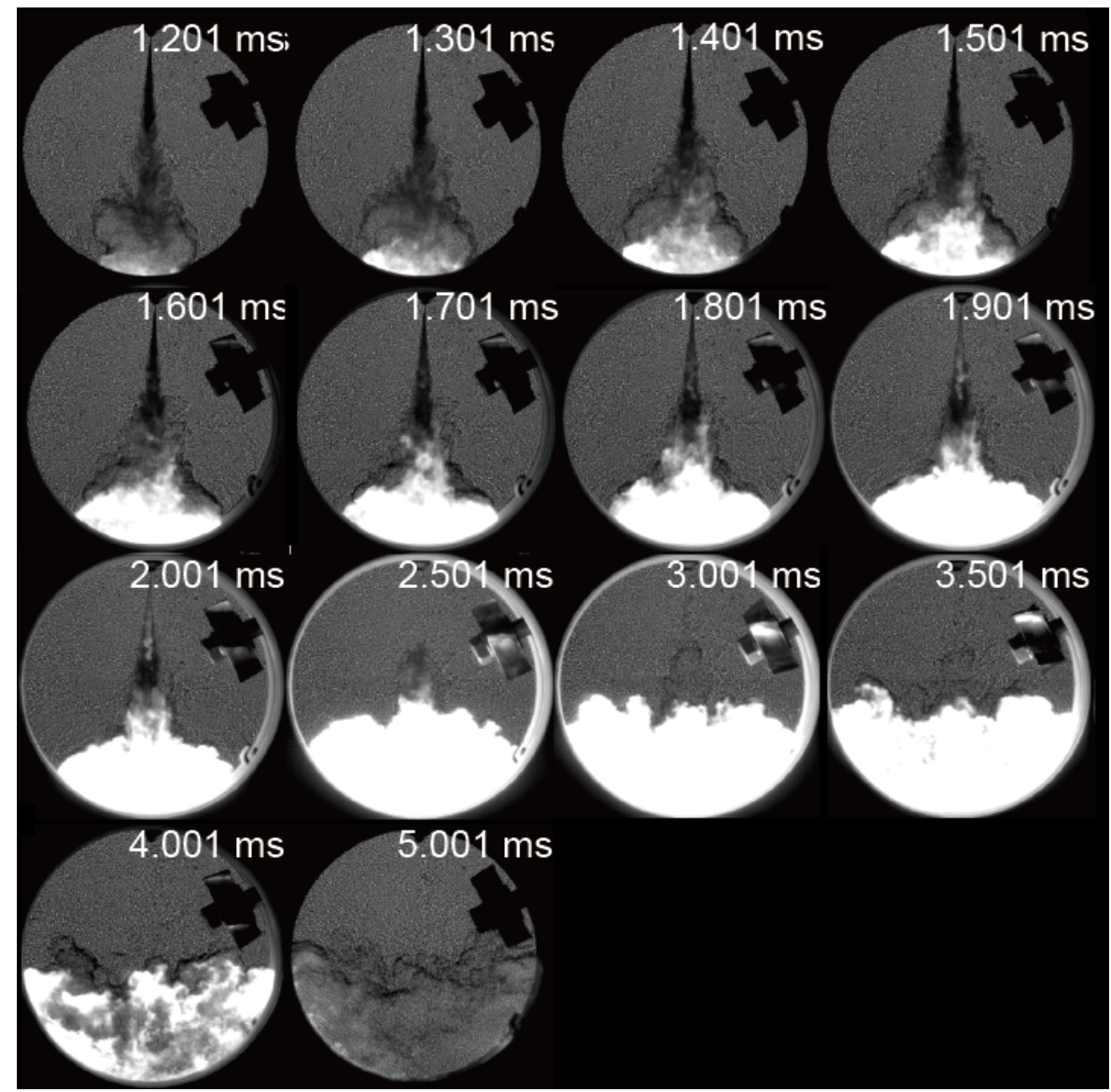

(b) Shadow graph image for combustion process $(C N=45)$

Figure 8 Spray development and combustion process 


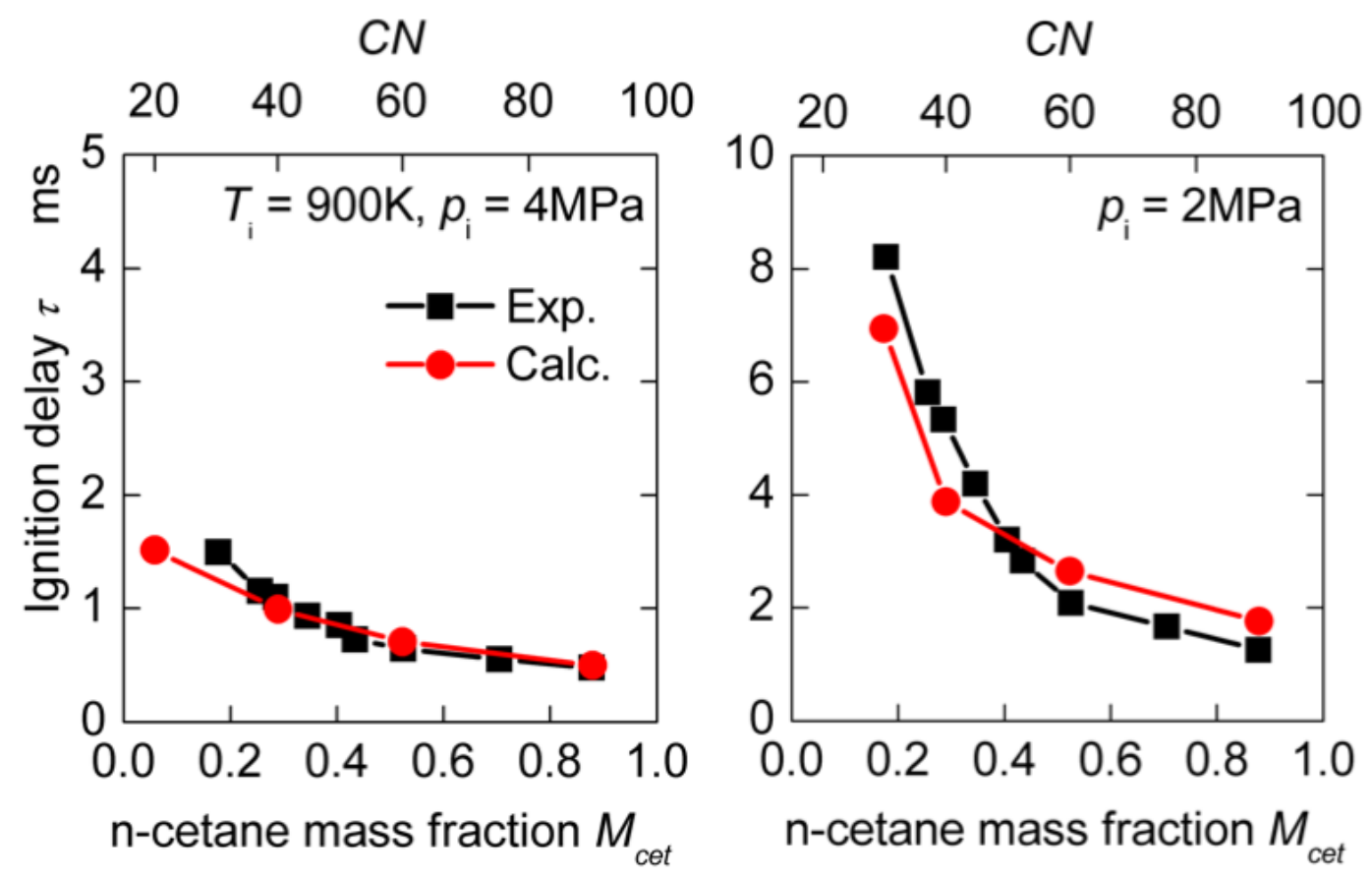

Figure 9 Change of ignition delay time $\tau$ against mass fraction of n-cetane 
Table 1 Reaction systems of larger molecular parts for n-cetane, HMN, n-heptane and i-octane

n-cetane Low Temperature Reactions

No.

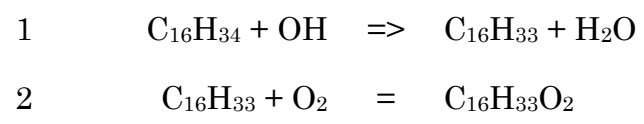

$\begin{array}{lll}A & B & E_{a}\end{array}$

$6.000 \mathrm{E}+14 \quad 0.00 \quad 3.000 \mathrm{E}+03$

$4.000 \mathrm{E}+13 \quad 0.00 \quad 0.000 \mathrm{E}+00$

3

$\mathrm{C}_{16} \mathrm{H}_{33} \mathrm{O}_{2}=\mathrm{C}_{16} \mathrm{H}_{32} \mathrm{OOH}$

$\operatorname{Rev} /$

$2.510 \mathrm{E}+13 \quad 0.00 \quad 2.740 \mathrm{E}+04$

$1.510 \mathrm{E}+11 \quad 0.00 \quad 1.900 \mathrm{E}+04$

Rev / $1.000 \mathrm{E}+11 \quad 0.00 \quad 1.100 \mathrm{E}+04$

$4 \quad \mathrm{C}_{16} \mathrm{H}_{32} \mathrm{OOH}+\mathrm{O}_{2}=\mathrm{O}_{2} \mathrm{C}_{16} \mathrm{H}_{32} \mathrm{OOH}$

$3.160 \mathrm{E}+11 \quad 0.00 \quad 0.000 \mathrm{E}+00$

Rev / $2.510 \mathrm{E}+13 \quad 0.00 \quad 2.740 \mathrm{E}+04$

$5 \quad \mathrm{O}_{2} \mathrm{C}_{16} \mathrm{H}_{32} \mathrm{OOH} \quad \Rightarrow \quad \mathrm{C}_{16} \mathrm{KET}+\mathrm{OH}$

$8.910 \mathrm{E}+10 \quad 0.00 \quad 1.700 \mathrm{E}+04$

6

$\mathrm{C}_{16} \mathrm{KET} \Rightarrow \mathrm{C}_{14} \mathrm{H}_{29} \mathrm{CO}+\mathrm{CH}_{2} \mathrm{O}+\mathrm{OH}$

$3.980 \mathrm{E}+15 \quad 0.00 \quad 4.300 \mathrm{E}+04$

$7 \quad \mathrm{C}_{14} \mathrm{H}_{29} \mathrm{CO}+\mathrm{O}_{2} \quad \Rightarrow \quad \mathrm{C}_{7} \mathrm{H}_{14}+\mathrm{C}_{7} \mathrm{H}_{14}+\mathrm{CO}+\mathrm{HO}_{2}$

$3.160 \mathrm{E}+13 \quad 0.00 \quad 1.000 \mathrm{E}+04$

8

$\mathrm{C}_{16} \mathrm{H}_{34}+\mathrm{O}_{2}=\mathrm{C}_{16} \mathrm{H}_{33}+\mathrm{HO}_{2}$

$2.000 \mathrm{E}+16 \quad 0.00 \quad 4.600 \mathrm{E}+04$

Rev / $1.000 \mathrm{E}+12 \quad 0.00 \quad 0.000 \mathrm{E}+00$

$9 \quad \mathrm{C}_{16} \mathrm{H}_{33}+\mathrm{O}_{2}=\mathrm{C}_{16} \mathrm{H}_{32}+\mathrm{HO}_{2}$

$6.320 \mathrm{E}+13 \quad 0.00 \quad 6.000 \mathrm{E}+03$

Rev / $3.160 \mathrm{E}+11 \quad 0.00 \quad 1.950 \mathrm{E}+04$

$10 \quad \mathrm{C}_{16} \mathrm{H}_{32}+\mathrm{O}_{2} \quad \Rightarrow \quad \mathrm{C}_{14} \mathrm{H}_{29}+\mathrm{CH}_{2} \mathrm{O}+\mathrm{HCO}$

$3.160 \mathrm{E}+13 \quad 0.00 \quad 1.000 \mathrm{E}+04$

11

$\mathrm{C}_{16} \mathrm{H}_{34}+\mathrm{HO}_{2}=\mathrm{C}_{16} \mathrm{H}_{33}+\mathrm{H}_{2} \mathrm{O}_{2}$

$1.000 \mathrm{E}+13 \quad 0.00 \quad 1.695 \mathrm{E}+04$

12

$\mathrm{C}_{16} \mathrm{H}_{33} \quad \Rightarrow \quad \mathrm{C}_{14} \mathrm{H}_{29}+\mathrm{C}_{2} \mathrm{H}_{4}$

$2.500 \mathrm{E}+13 \quad 0.00 \quad 2.881 \mathrm{E}+04$

13

$\mathrm{C}_{14} \mathrm{H}_{29}=\mathrm{C}_{5} \mathrm{H}_{11}+\mathrm{C}_{3} \mathrm{H}_{6}+3 \mathrm{C}_{2} \mathrm{H}_{4}$

$1.138 \mathrm{E}+15 \quad-0.42 \quad 2.701 \mathrm{E}+04$ 
HMN Low Temperature Reactions

\begin{tabular}{|c|c|c|c|c|c|c|}
\hline No. & & & & $A$ & $B$ & $E_{a}$ \\
\hline 14 & $\mathrm{IC}_{16} \mathrm{H}_{34}+\mathrm{OH}$ & $=>$ & $\mathrm{IC}_{16} \mathrm{H}_{33}+\mathrm{H}_{2} \mathrm{O}$ & $6.000 \mathrm{E}+13$ & 0.00 & $3.000 \mathrm{E}+03$ \\
\hline \multirow[t]{2}{*}{15} & $\mathrm{IC}_{16} \mathrm{H}_{33}+\mathrm{O}_{2}$ & $=$ & $\mathrm{IC}_{16} \mathrm{H}_{33} \mathrm{O}_{2}$ & $5.000 \mathrm{E}+12$ & 0.00 & $0.000 \mathrm{E}+00$ \\
\hline & & & Rev / & $2.510 \mathrm{E}+13$ & 0.00 & $2.740 \mathrm{E}+04$ \\
\hline \multirow[t]{2}{*}{16} & $\mathrm{IC}_{16} \mathrm{H}_{33} \mathrm{O}_{2}$ & $=$ & $\mathrm{IC}_{16} \mathrm{H}_{32} \mathrm{OOH}$ & $1.510 \mathrm{E}+11$ & 0.00 & $2.180 \mathrm{E}+04$ \\
\hline & & & $\operatorname{Rev} /$ & $1.000 \mathrm{E}+11$ & 0.00 & $1.100 \mathrm{E}+04$ \\
\hline \multirow[t]{2}{*}{17} & $\mathrm{IC}_{16} \mathrm{H}_{32} \mathrm{OOH}+\mathrm{O}_{2}$ & $=$ & $\mathrm{IO}_{2} \mathrm{C}_{16} \mathrm{H}_{32} \mathrm{OOH}$ & $1.264 \mathrm{E}+12$ & 0.00 & $0.000 \mathrm{E}+00$ \\
\hline & & & Rev / & $2.510 \mathrm{E}+13$ & 0.00 & $2.740 \mathrm{E}+04$ \\
\hline 18 & $\mathrm{IO}_{2} \mathrm{C}_{16} \mathrm{H}_{32} \mathrm{OOH}$ & $\Rightarrow$ & $\mathrm{IC}_{16} \mathrm{KET}+\mathrm{OH}$ & $8.910 \mathrm{E}+10$ & 0.00 & $1.700 \mathrm{E}+04$ \\
\hline 19 & $\mathrm{IC}_{16} \mathrm{KET}$ & $=>$ & $\mathrm{IC}_{14} \mathrm{H}_{29} \mathrm{CO}+\mathrm{CH}_{2} \mathrm{O}+\mathrm{OH}$ & $3.980 \mathrm{E}+15$ & 0.00 & $4.300 \mathrm{E}+04$ \\
\hline 20 & $\mathrm{IC}_{14} \mathrm{H}_{29} \mathrm{CO}+\mathrm{O}_{2}$ & $=>$ & $\mathrm{IC}_{8} \mathrm{H}_{17}+\mathrm{C}_{3} \mathrm{H}_{6}+\mathrm{C}_{3} \mathrm{H}_{5}+\mathrm{CO}+\mathrm{HO}_{2}$ & $3.160 \mathrm{E}+13$ & 0.00 & $1.000 \mathrm{E}+04$ \\
\hline \multirow[t]{2}{*}{21} & $\mathrm{IC}_{16} \mathrm{H}_{34}+\mathrm{O}_{2}$ & $=$ & $\mathrm{IC}_{16} \mathrm{H}_{33}+\mathrm{HO}_{2}$ & $1.000 \mathrm{E}+15$ & 0.00 & $4.600 \mathrm{E}+04$ \\
\hline & & & Rev / & $1.000 \mathrm{E}+12$ & 0.00 & $0.000 \mathrm{E}+00$ \\
\hline \multirow[t]{2}{*}{22} & $\mathrm{IC}_{16} \mathrm{H}_{33}+\mathrm{O} 2$ & $=$ & $\mathrm{IC}_{16} \mathrm{H}_{32}+\mathrm{HO}_{2}$ & $3.160 \mathrm{E}+13$ & 0.00 & $6.000 \mathrm{E}+03$ \\
\hline & & & $\operatorname{Rev} /$ & $3.160 \mathrm{E}+11$ & 0.00 & $1.950 \mathrm{E}+04$ \\
\hline 23 & $\mathrm{IC}_{16} \mathrm{H}_{32}+\mathrm{O}_{2}$ & $\Rightarrow$ & $\mathrm{IC}_{14} \mathrm{H}_{29}+\mathrm{CH}_{2} \mathrm{O}+\mathrm{HCO}$ & $3.160 \mathrm{E}+13$ & 0.00 & $1.000 \mathrm{E}+04$ \\
\hline 24 & $\mathrm{IC}_{16} \mathrm{H}_{34}+\mathrm{HO}_{2}$ & $=$ & $\mathrm{IC}_{16} \mathrm{H}_{33}+\mathrm{H}_{2} \mathrm{O}_{2}$ & $1.000 \mathrm{E}+13$ & 0.00 & $1.695 \mathrm{E}+04$ \\
\hline 25 & $\mathrm{IC}_{16} \mathrm{H}_{33}$ & $=>$ & $\mathrm{IC}_{14} \mathrm{H}_{29}+\mathrm{C}_{2} \mathrm{H}_{4}$ & $3.617 \mathrm{E}+17$ & -1.27 & $2.970 \mathrm{E}+04$ \\
\hline 26 & $\mathrm{IC}_{14} \mathrm{H}_{29}$ & $=$ & $\mathrm{IC}_{8} \mathrm{H}_{17}+\mathrm{C}_{3} \mathrm{H}_{6}+\mathrm{C}_{3} \mathrm{H}_{6}$ & $7.204 \mathrm{E}+13$ & -0.03 & $2.790 \mathrm{E}+04$ \\
\hline
\end{tabular}


n-heptane Low Temperature Reactions

No.

27

28

29

30

31

32

33

34

35

36

37

38

39

$$
\begin{aligned}
\mathrm{C}_{7} \mathrm{H}_{16}+\mathrm{OH} & =>\mathrm{C}_{7} \mathrm{H}_{15}+\mathrm{H}_{2} \mathrm{O} \\
\mathrm{C}_{7} \mathrm{H}_{15}+\mathrm{O}_{2} & =\mathrm{C}_{7} \mathrm{H}_{15} \mathrm{O}_{2}
\end{aligned}
$$$$
\mathrm{C}_{7} \mathrm{H}_{15} \mathrm{O}_{2}=\mathrm{C}_{7} \mathrm{H}_{14} \mathrm{OOH}
$$$$
\mathrm{C}_{7} \mathrm{H}_{14} \mathrm{OOH}+\mathrm{O}_{2}=\mathrm{O}_{2} \mathrm{C}_{7} \mathrm{H}_{14} \mathrm{OOH}
$$$$
\mathrm{O}_{2} \mathrm{C}_{7} \mathrm{H}_{14} \mathrm{OOH} \quad=\quad \mathrm{C}_{7} \mathrm{KET}+\mathrm{OH}
$$$$
\mathrm{C}_{7} \mathrm{KET} \Rightarrow \mathrm{C}_{5} \mathrm{H}_{11} \mathrm{CO}+\mathrm{CH}_{2} \mathrm{O}+\mathrm{OH}
$$$$
\mathrm{C}_{5} \mathrm{H}_{11} \mathrm{CO}+\mathrm{O}_{2} \Rightarrow \mathrm{C}_{3} \mathrm{H}_{7}+\mathrm{C}_{2} \mathrm{H} 3+\mathrm{CO}+\mathrm{HO}_{2}
$$$$
\mathrm{C}_{7} \mathrm{H}_{16}+\mathrm{O}_{2}=\mathrm{C}_{7} \mathrm{H}_{15}+\mathrm{HO}_{2}
$$

35

$$
\mathrm{C}_{7} \mathrm{H}_{15}+\mathrm{O}_{2}=\mathrm{C}_{7} \mathrm{H}_{14}+\mathrm{HO}_{2}
$$

$\operatorname{Rev} /$

Rev /

$$
\text { A }
$$

$2.400 \mathrm{E}+14$

$6.000 \mathrm{E}+12$

$2.510 \mathrm{E}+13$

$1.510 \mathrm{E}+11$

Rev /

$1.000 \mathrm{E}+11$

$3.160 \mathrm{E}+11$

0.00

$2.510 \mathrm{E}+13$

0.00

$8.910 \mathrm{E}+10$

0.00

$2.388 \mathrm{E}+15 \quad 0.00$

$3.160 \mathrm{E}+13$

0.00

$1.000 \mathrm{E}+16$

0.00

$1.000 \mathrm{E}+12 \quad 0.00 \quad 0.000 \mathrm{E}+00$

$12.64 \mathrm{E}+12 \quad 0.00 \quad 6.000 \mathrm{E}+03$

Rev /

$3.160 \mathrm{E}+11 \quad 0.00 \quad 1.950 \mathrm{E}+04$

$3.160 \mathrm{E}+13 \quad 0.00 \quad 1.000 \mathrm{E}+04$

$1.000 \mathrm{E}+13 \quad 0.00 \quad 1.695 \mathrm{E}+04$

$2.500 \mathrm{E}+13 \quad 0.00 \quad 2.881 \mathrm{E}+04$

$1.138 \mathrm{E}+15-0.42 \quad 2.701 \mathrm{E}+04$ 
i-octane Low Temperature Reactions

No.

$$
\begin{aligned}
& 40 \quad \mathrm{IC}_{8} \mathrm{H}_{18}+\mathrm{OH} \Rightarrow \mathrm{IC}_{8} \mathrm{H}_{17}+\mathrm{H}_{2} \mathrm{O} \\
& 41 \\
& 42 \\
& \mathrm{IC}_{8} \mathrm{H}_{17} \mathrm{O}_{2}=\mathrm{IC}_{8} \mathrm{H}_{16} \mathrm{OOH} \\
& \mathrm{IC}_{8} \mathrm{H}_{17}+\mathrm{O}_{2}=\mathrm{IC}_{8} \mathrm{H}_{17} \mathrm{O}_{2}
\end{aligned}
$$$$
43
$$$$
\mathrm{IC}_{8} \mathrm{H}_{16} \mathrm{OOH}+\mathrm{O}_{2}=\mathrm{IO}_{2} \mathrm{C}_{8} \mathrm{H}_{16} \mathrm{OOH}
$$$$
44
$$$$
45
$$$$
46
$$$$
47
$$$$
48
$$$$
49
$$$$
50
$$$$
51
$$

52$$
\mathrm{IC}_{8} \mathrm{H}_{17}+\mathrm{O}_{2}=\mathrm{IC}_{8} \mathrm{H}_{16}+\mathrm{HO}_{2}
$$

$$
\begin{aligned}
& \mathrm{IO}_{2} \mathrm{C}_{8} \mathrm{H}_{16} \mathrm{OOH} \Rightarrow \mathrm{IC}_{8} \mathrm{KET}+\mathrm{OH} \\
& \mathrm{IC}_{8} \mathrm{KET} \Rightarrow \mathrm{C}_{6} \mathrm{H}_{13} \mathrm{CO}+\mathrm{CH}_{2} \mathrm{O}+\mathrm{OH} \\
& \mathrm{C}_{6} \mathrm{H}_{13} \mathrm{CO}+\mathrm{O}_{2} \quad \Rightarrow \quad \mathrm{C}_{3} \mathrm{H}_{6}+\mathrm{C}_{3} \mathrm{H}_{6}+\mathrm{CO}+\mathrm{HO}_{2} \\
& \mathrm{IC}_{8} \mathrm{H}_{18}+\mathrm{O}_{2}=\mathrm{IC}_{8} \mathrm{H}_{17}+\mathrm{HO}_{2}
\end{aligned}
$$

$$
\begin{aligned}
\mathrm{IC}_{8} \mathrm{H}_{16}+\mathrm{O}_{2} & \Rightarrow \mathrm{C}_{6} \mathrm{H}_{13}+\mathrm{CH}_{2} \mathrm{O}+\mathrm{HCO} \\
\mathrm{IC}_{8} \mathrm{H}_{18}+\mathrm{HO}_{2} & =\mathrm{IC}_{8} \mathrm{H}_{17}+\mathrm{H}_{2} \mathrm{O}_{2} \\
\mathrm{IC}_{8} \mathrm{H}_{17} & =>\mathrm{C}_{6} \mathrm{H}_{13}+\mathrm{C}_{2} \mathrm{H}_{4} \\
\mathrm{C}_{6} \mathrm{H}_{13} & =\mathrm{C}_{3} \mathrm{H}_{7}+\mathrm{C}_{3} \mathrm{H}_{6}
\end{aligned}
$$

Rev /

$\operatorname{Rev} /$

$\begin{array}{cccc} & A & B & E_{a} \\ & 6.000 \mathrm{E}+13 & 0.00 & 3.000 \mathrm{E}+03 \\ & 18.00 \mathrm{E}+12 & 0.00 & 0.000 \mathrm{E}+00 \\ \text { Rev / } & 2.510 \mathrm{E}+13 & 0.00 & 2.740 \mathrm{E}+04 \\ & 1.510 \mathrm{E}+11 & 0.00 & 2.180 \mathrm{E}+04 \\ \text { Rev / } & 1.000 \mathrm{E}+11 & 0.00 & 1.100 \mathrm{E}+04 \\ & 3.160 \mathrm{E}+11 & 0.00 & 0.000 \mathrm{E}+00 \\ \text { Rev / } & 2.510 \mathrm{E}+13 & 0.00 & 2.740 \mathrm{E}+04 \\ & 8.910 \mathrm{E}+10 & 0.00 & 1.700 \mathrm{E}+04 \\ & 3.980 \mathrm{E}+14 & 0.00 & 4.300 \mathrm{E}+04 \\ & 3.160 \mathrm{E}+13 & 0.00 & 1.000 \mathrm{E}+04 \\ & 1.000 \mathrm{E}+16 & 0.00 & 4.600 \mathrm{E}+04 \\ \text { Rev / } & 1.000 \mathrm{E}+12 & 0.00 & 0.000 \mathrm{E}+00 \\ & 9.480 \mathrm{E}+12 & 0.00 & 6.000 \mathrm{E}+03 \\ \text { Rev / } & 3.160 \mathrm{E}+11 & 0.00 & 1.950 \mathrm{E}+04 \\ & 3.160 \mathrm{E}+13 & 0.00 & 1.000 \mathrm{E}+04 \\ & 1.000 \mathrm{E}+13 & 0.00 & 1.695 \mathrm{E}+04 \\ & 3.617 \mathrm{E}+17 & -1.27 & 2.970 \mathrm{E}+04 \\ & 7.204 \mathrm{E}+13 & -0.03 & 2.790 \mathrm{E}+04\end{array}$

